\title{
CARTOGRAPHIC ANALYSIS OF TOURIST ATTRACTIVE REGIONS USING GIS TECHNOLOGIES
}

\author{
Viktoriia LEPETIUK (1D) \\ Geoinformation Systems for Territory Management Department, \\ Kyiv National University of Construction and Architecture, Kyiv, Ukraine
}

Received 16 December 2019; accepted 06 December 2020

\begin{abstract}
In this article, I compare cartographic methods that can be used for analyzing tourist attractive regions and explore the possibilities of using GIS technologies for such analysis. I provide a specific methodology of searching for the most attractive tourist regions using Voronoi diagrams and heatmaps. I demonstrate the methodology by applying it to certain types of tourist resources in Chernihiv region of Ukraine.
\end{abstract}

Keywords: tourist destinations, cartographic method, tourist attractive region, GIS technologies, historical and cultural object, QGIS.

\section{Introduction}

Finding tourist attractive regions is an important task for the development of tourism. Searching for such territories is important for tourists, managers of tourism, as well as for central and local executive branches. There are many specialized cartographic productions in the tourism industry that are created for tourists and tour operators. On the other hand, there is a certain lack of such productions for those who manage the tourism industry. The need of the latter products is clear since they are useful for the decision making in the tourism industry.

Modern technologies, especially GIS technologies, can significantly help in the decision making. They can serve as powerful tools in determining tourist attractiveness. With their help, for example, a high-quality territorial planning scheme can be developed. A cartographic analysis of a territory allows determining the levels of tourism development in their regions, planning tourism activities and improving the management efficiency. These activities are very relevant and important, as the role of tourism in the development of the modern economy is increasing.

\section{Analysis of recent publications}

GIS can be a very powerful tool for analysis and integrated assessment of tourism resources. Many authors consider their use to be very promising. The introduction of GIS technologies in the tourism industry is studied by such authors as Kruzhalin, Mironenko, Zigern-Korn, and Shabalina (2014), Barliani (2015), Melkonian (2019), Umrik (2011), Melnik (2009), Shnyirkova and Zhihareva (2016), Kulyk and Sossa (2018).

Yakovenko (2003) notes the insufficiency of the level of modern organization of statistical research in the field of recreation and tourism. Melnik (2009) writes about the need to include databases of specialized digital maps that characterize recreational facilities into the GIS of the tourism industry. Shnyirkova and Zhihareva (2016) study the use of GIS to create a territorial planning scheme in tourism using a river basin as an example. Tagan (2009) considers the use of cartographic methods in the study of territorial recreational inequality. Kulyk and Sossa (2018) explore the possibilities of using heatmaps to study the tourist attractiveness of regions.

Nonetheless, a comparison of cartographic methods for analyzing the tourist attractiveness of regions has not been carried out, and therefore it is valuable for the study of tourist resources of a territory with the aim of developing tourism.

\section{Methodology and data}

Tourism as a complex and multi-factorial system consists of the following components: a tourism product, a tourism subject, a tourism participant, an object and an organizer (Izotova \& Matyuhina, 2006). The tourism product is a combination of tourism services and tours. The subject of

*Corresponding author. E-mail: lepetiuk.vb@knuba.edu.ua 
tourism consists of tourism enterprises and organizations of travel. The tourism participant is a tourist who uses the products and services of the tourism system. The tourism object is understood as the entire sphere of all tourismrelated services (food, accommodation, transport, cultural institutions, natural, cultural, historical, sports, recreational and other facilities). The organizer is a business company or an individual entrepreneur who plans and implements tourist events or programs, creates and distributes a tourism product. The tourism object is the basis of the tourism system. In essence, tourism is based on tourist attractions that draw steady tourist flows to their location. Among all components this element is the most fundamental as without it the need for the development of tourism services disappears.

Alternatively the tourism system can be viewed as a system of relations in which tourism enterprises, organizations and regions interact with the external environment. This system is closely related to economy, ecology, technology, politics and the social system (Pshenichnyih, 2006).

The tourist attractiveness of an area is also a complex concept. This concept has a touch of subjectivity and it depends on a particular category of users of travel services. It takes into account the availability of tourism facilities and tourist infrastructure as well as the ability of a tour operator to properly use the resources of the area, create a positive image of the territory and correctly inform the final consumer, i.e., the tourist.

To obtain effective results in the tourism sector, a particularly important aspect of the tour operator's work is a study of consumer demand. Tour operators are interested in knowing what is relevant for a tourist, what target audience a tourist product is suitable for, what opportunities a territory offers (Vishnyakova, 2015). The cartographic research method in combination with GIS technologies can significantly help in answering these questions.

Most methods of finding the tourist attractive regions use a comprehensive assessment of resources. Such an assessment is also important for a development of a territorial planning scheme. As a part of the assessment, cartographic elements are determined. Among them are basic elements of the natural and cultural landscape, tourism resources and infrastructure.

\section{Chernihiv region as a tourist destination}

Because my task is to use cartographic methods to develop a methodology for analyzing the tourist attractive regions, I limit my analysis to a particular region of Ukraine. The region of my choice is Chernihiv region. This historic region has favorable conditions for development of various types of tourism. As of today, over 9000 cultural heritage monuments are registered in the region, about 1900 of which are of national importance. Fourteen settlements of the region are included in the list of historical settlements of Ukraine; three of them have a thousand year history (Chernihiv, Novhorod-Siverskyi, urban village Liubech).
There are 37 museums in the region, including three museums of national status ("Ancient Chernihiv", "Hetman capital", "Kachanivka") and one memorial complex ("Kruty Heroes Memorial"). By the number of museums, Chernihiv region ranks third in Ukraine (after Kyiv region and Poltava region).

Chernihiv region today is not among the top tourist regions of the country. Nowadays the most developed and attractive destinations of Ukraine are Kyiv city and Kyiv region, Lviv city and Lviv region, Odessa, Crimea, Carpathian region. However, Chernihiv region has significant potential for tourism development. These facts make the region especially interesting for research.

\section{Study area}

It is quite difficult to analyze all tourist attractions in such a large region as Chernihiv region. Open data are becoming increasingly popular. The Ukrainian government created the unified state open data portal Data.gov. ua, however, local authorities of Chernihiv region have not yet released any information there. Therefore, I use data from an internet service OpenStreetMap (OSM). This is a non-profit mapping project aimed to create a detailed free of charge geographical map of the world. However, its use for solving some practical tasks is fairly problematic. OSM data may be incomplete, outdated or invalid. In such data there are tourist objects without attributes or with an imprecise location.

In this study, I analyze methodologies for finding tourist attractive regions, and seek to gain practical experience in such an analysis. Therefore, I concentrate on studying only such tourism objects as historical and cultural objects. In QGIS program, I create a table "Cultural objects" with data on the most famous historical and cultural objects of Chernihiv region. In this table, there are 241 such objects from OSM (Figure 1). These objects are included based on reviews of tourists who visited them. In particular, among all tourist objects in OSM, I select those objects that were highly rated by Google reviewers. It is reasonable to assume that they are more popular and more often visited by tourists. These objects are such tourist attractions as museums, theaters, sacred objects, parks, estates, palaces, monuments, architectural buildings, viewpoints and others. It is worth noting that not all of these objects are represented in the initial database as point objects. Those of them that have the form of polygons, I transform into point objects. Their point locations are set on the map by the centroids of the polygons. Thus, they are also included in the analysis of tourist attractive regions.

In Figure 2 it can be seen that on a map of the studied region of a small scale (1: 2500000$)$, some objects overlap each another. This overlapping complicates an analysis of this territory. It could be noted that the tourist objects are not always tied to the centers of districts or to hydrographic objects. If objects of tourist infrastructure were added to the map, the analysis of this territory would be further complicated. Since it is visually difficult to analyze 


\begin{tabular}{|c|c|c|c|c|c|c|c|}
\hline & id & $\nabla$ & name & adress & date & adress_eng & Name_engl \\
\hline 4 & & & П'яттицька церква & вул. Полуботка, 10/2 & At the end of the 12 th $c$. & Chernitiv & Friday Church \\
\hline 5 & & & Катерининська церква & вуп.Підвальна, 5 & $1715 \mathrm{y}$ & Chernihiv & Catherine church \\
\hline 6 & & 7 & Елецький монвстир & вул.Князя Чорного, 1 & 11-17thc. & Chernihiv & Yelets Monastery \\
\hline 7 & & 8 & Аввіница & вул.Князя Чорного, 1 & At the end of the 17 th $c$. & Chernitiv & Bell tower \\
\hline 8 & & & Kenii & Еул.Князя Чорного, 1 & 17the. & Chernihiv & Cells \\
\hline 9 & & 9 & Будинок Феодосяя & Вулп.Князя Чорного, 1 & $1688 \mathrm{y}$. & Chernihiv & Theodosius House \\
\hline 10 & & 10 & Іллінський монастир & вул.ІІлиінська, 29 & 11-18thc. & Chernihiv & Illinskyi Monastery \\
\hline 11 & & 11 & Іллінська церква & вул.Гллінська, 29 & $1069 \mathrm{y}$. & Chernihiv & Illia Church \\
\hline 12 & & 12 & Антоніiеsi печери & вул.Iлnлінсқка, 29 & 11-17thc. & Cheminiv & Antoni caves \\
\hline 13 & & 13 & Комплекс споруд Троїького монастиря & вуп. Толстого, 92-E & 17-18thc. & Chernihiv & Complex of buildings of the Trinity Monastery \\
\hline 14 & & 14 & Будинок губернатора & вул.Музейна, 4 & $1821 \mathrm{y}$ & Chernihiv & Governor's House \\
\hline 15 & & 15 & Будинок архігпископа & вул.Зелена, 2 & $1730 \mathrm{y}$. & Chernitiv & Archbishop's House \\
\hline 16 & & 16 & Восқресенська черква & вул.Ремісснича, 36 & $1772-1779$ ys. & Chernihiv & Sunday Church \\
\hline 17 & & 17 & Папац К.Pозутовссскокого & Батурин.Вул.Наберекна, 1 & 1799-1803 ys. & Baturym & K.Rourmovskyi Palace \\
\hline 18 & & 18 & Воскресенська церква & Батурин & $1803 y$. & Baturyn & Sunday Church \\
\hline 19 & & 19 & Крупицько- -ат уринсский монастир & Odi & 17-19thc. & Osich & Krupytsko-Baturyn Monastery \\
\hline 20 & & 20 & Буминок Кочубея & Батурин,Вул.Гетьманскка & At the end of the 18 th $c$. & Baturyn & Kochubei House \\
\hline 21 & & 21 & Tроївка Lерквва & с.Нові плини & $1800 \mathrm{y}$. & Novimlyny & Trinity Church \\
\hline 22 & & 22 & Михайлівсска церква & с.Вегикий Листвен & $1742 y$. & Velykyi Lystven & St. Michael's Church \\
\hline 23 & & 23 & Жачатіiвка» & c.Качаніiвка & 18-19th c. & Kachanivka & Kachanivka \\
\hline 24 & & 24 & Аенаропарк Тростянець & Тростянешь & 1834-1864ys. & Trostianets & Trostianets Arboretum \\
\hline 25 & & 25 & Co6ор Pisasa Бо гороаицن & Козелешь,вул. Даневича, 2 & $1752-1766$ ys. & Kozelets & Sobor Rizdva Bohorodytsi \\
\hline
\end{tabular}

Figure 1. A fragment of table "Cultural objects" of Chernihiv region

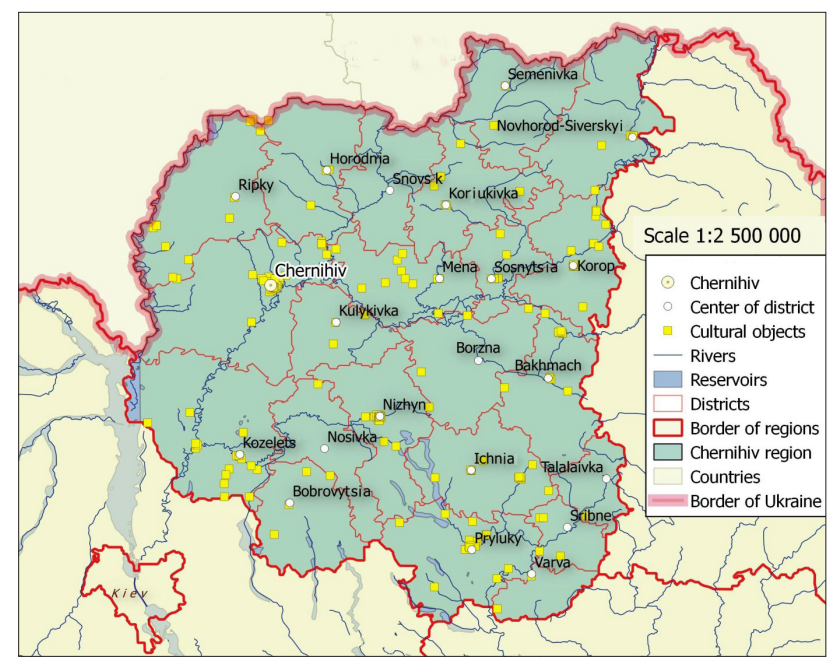

Figure 2. A map of historical and cultural objects of Chernihiv region

the number of tourist objects at each location, for an indepth analysis of the tourist attractiveness of the territory, I propose to consider 4 cartographic methods: a chart diagram, a cartogram, a search for the nearest neighbor and a density surface analysis.

\subsection{The first cartographic method}

First of all, I study the distribution of historical and cultural objects of Chernihiv region by administrative districts. This study is important for choosing the most attractive tourist destination areas. In Figure 3 I present a map of the distribution of historical and cultural objects by districts using the method of a chart diagram. On the map constructed according to this method the absolute number of historical and cultural objects in the districts is shown in the form of diagrams. This mapping is simply done by counting the number of objects in each district and assembling the corresponding bar charts.

The constructed map shows that Chernihiv district is the most attractive for tourists. This district has the largest number of historical and cultural objects. Next in the ranking are Nizhyn district, Pryluky district and Kozelets district. Snovsk district, in which there are no tourist objects, appears to be the least attractive. Thus, this cartographic method allows to highlight the most and least attractive administrative districts. Such mapping could visually complement statistical reports.

The analysis of the territory by the method of a chart diagram does not reveal any significant pattern in the distribution of tourist attractive objects. The most attractive areas are located irregularly in Chernihiv region; there is no one clear part of the region where tourist attractiveness is expressed most or least visibly. On the map (Figure 3) it can be seen that larger numbers of historical and cultural objects are located in the region in certain areas. These areas consist of districts with cities of regional significance that have the largest population in the region (Chernihiv 288.9 thousand people, Nizhyn -68.6 thousand people, Pryluky - 54.7 thousand people), as well as a district with an urban village Kozelets. However, these areas are geographically separated and do not constitute one common area. This fact suggests to consider relative indicators and look for alternative patterns in the distribution of histori$\mathrm{cal}$ and cultural objects that are related to the number of people or to the size of an area.

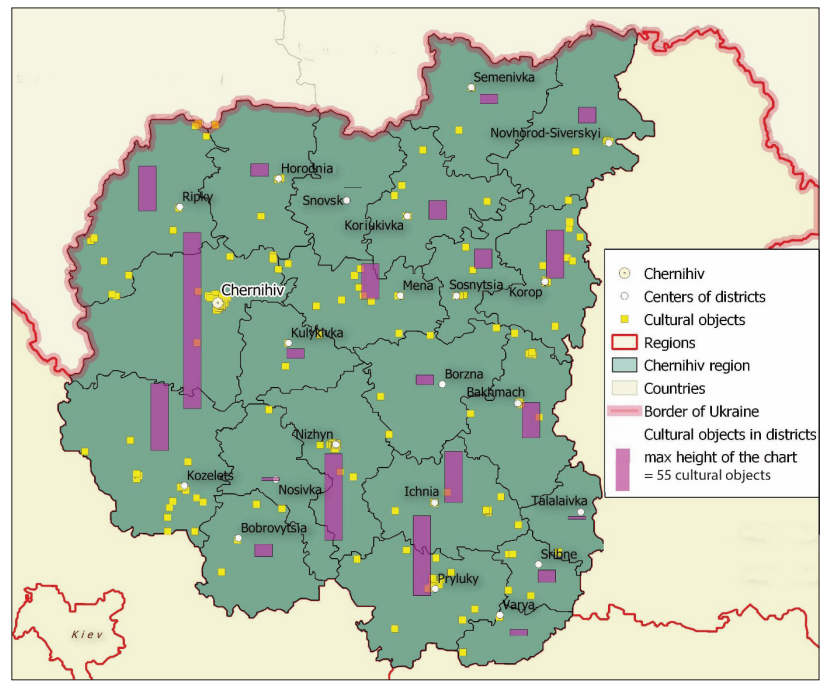

Figure 3. A chart diagram showing the number of historical and cultural objects in the districts 


\subsection{The second cartographic method}

The second cartographic method that I consider is the cartogram method. This method of mapping allows to show the distribution of a relative indicator within the administrative units of the map (Kulyk \& Sossa, 2018, Salishchev, 1990). In Figures 4 and 5 I show the distribution of historical and cultural objects of Chernihiv region by the method of cartograms within the administrative districts. In Figure 4 I present the number of such objects relative to the population of each district (as of 2018). In Figure 5 I make a similar calculation relative to the area of each district. For a qualitative presentation of results, a scale consisting of 7 gradations is chosen.

The study shows that the highest density of distribution of historical and cultural objects according to the two

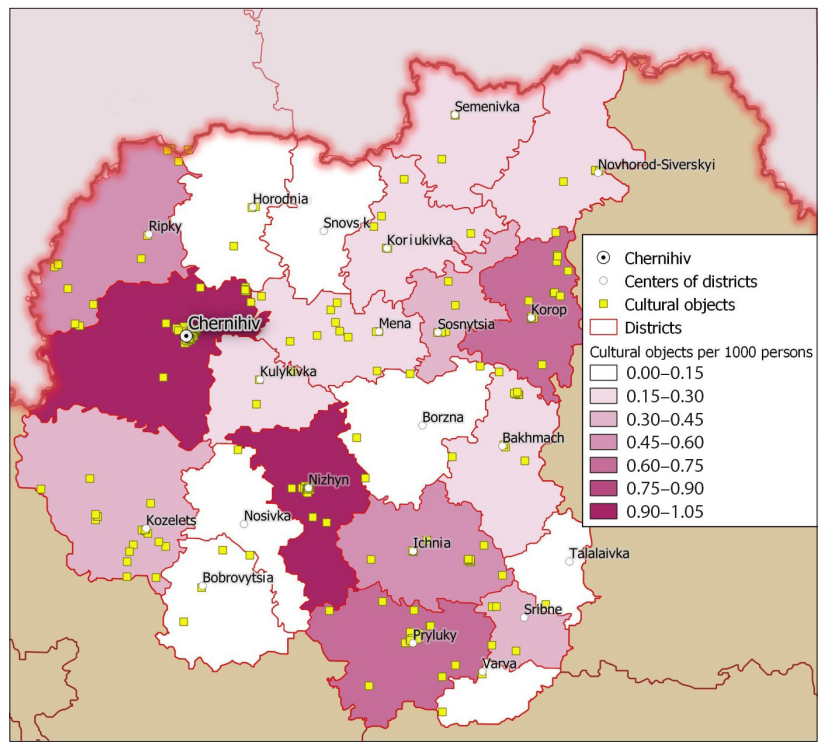

Figure 4. A cartogram showing the number of historical and cultural objects relatively to the number of population in districts

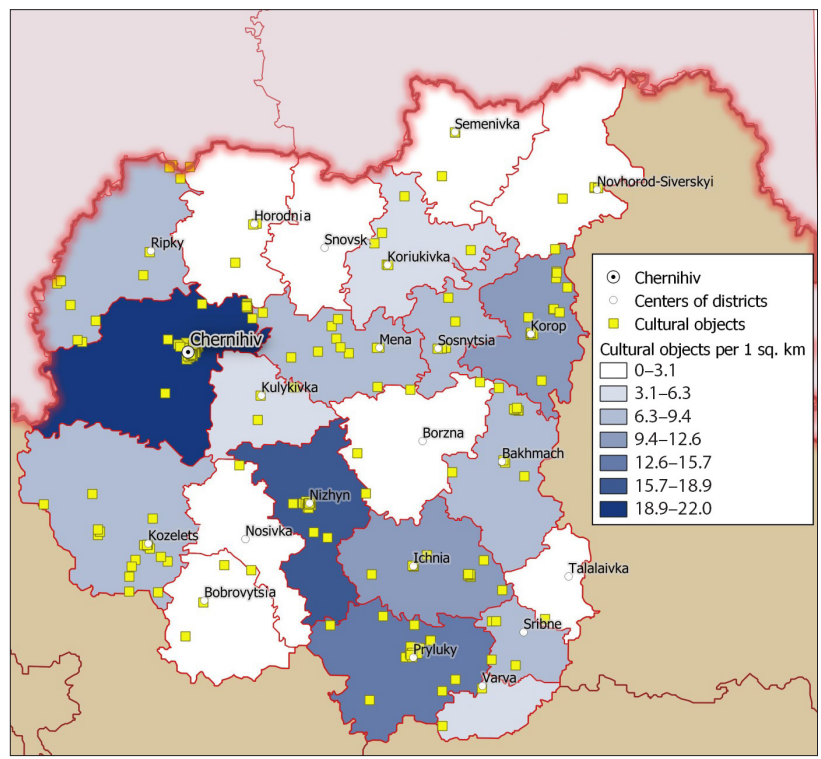

Figure 5. A cartogram showing the number of historical and cultural objects relatively to the area of the districts relative measures is in Chernihiv district and in Nizhyn district Furthermore, in the analysis of the number of historical and cultural objects relative to the number of inhabitants, regions that are lagging behind are clearly visible. They are Horodnia, Snovsk, Nosivka, Borzna, Bobrovytsia and Varva districts. In the districts, perhaps, it makes sense to focus on tourist attractions other than historical and cultural objects to strengthen the role of tourism in the economy of these districts. The analysis of the last two maps also reveals an interesting fact. Two districts (Semenivka district and Novhorod-Siverskyi district) have not very low indicators of the number of objects relatively to the number of people (Figure 4). However on the map in Figure 5 they have the lowest value on the index scale. These facts indicate that the area of these districts allows to develop tourism activities much more actively. In these districts there are a sufficient number of potential tourism subjects and a necessary resource (territory) to increase the number of tourism participants and tourism products.

It is worth noting that the analysis of a territory by administrative districts has a significant disadvantage for the subject and participant of tourism, i.e., a particular tourist. Typically, a tourist visits cultural or historical sites without paying much attention to the administrative subdivision of the territory.

\subsection{The third cartographic method}

For a cartographic analysis of the regions that is more informative for an individual tourist, I propose the construction of a partition known as a Voronoi diagram. This partition is based on the method of finding the nearest neighbor. This method consists of finding among the set of elements those that are close to a given one according to some given measure function (Preparata \& Sheymos, 1989).

A Voronoi diagram (also known as a Voronoi Mosaic) is a partition of the territory on a plane. Each area of this partition is formed by a set of points. The points are closer to one specific element of the set than to any other specific elements that form the other sets (Preparata \& Sheymos, 1989). A Voronoi diagram is used in cartography to outline boundaries of regions and conduct further analysis based on them. It is used in finding, for example, the nearest interesting object and for various searches and location analyses.

The Voronoi diagram consists of the so-called "loci" (polygons or Voronoi cells). In the Voronoi diagram, loci are convex polygons (Zaharkin, 2016). Importantly, they do not coincide with administrative boundaries of regions. This feature makes the partition more natural.

In my research using QGIS, I build loci around the centers of districts. These centers typically have developed tourism infrastructure, in particular, hotels. The border of each locus defines the territory that is the closest to the center of the district. Then, the number of historical and cultural objects within each locus is calculated. According to the number of objects inside each locus, I color the loci 
on an index scale, divided into 5 gradations of color. Figure 6 presents the Voronoi diagram of Chernihiv region.

The Voronoi diagram in Figure 6 shows that the largest number of historical and cultural objects is around Chernihiv. A slightly smaller concentration of them is near Nizhyn, Pryluky, and Kozelets. In terms of tourist attractiveness the following are the regions around Korop, Ichnia, Bakhmach, Ripky and Horodnia.

More accurate search for tourism facilities can be obtained from a Voronoi diagram with smaller loci. This can be done by constructing polygons also around smaller settlements such as urban settlements and villages.

In Figure 7, I show the Voronoi diagram of historical and cultural objects of Chernihiv region with smaller loci. This diagram allows us to localize on the map more accurately the clusters of territories attractive for tourists. After mapping hotels and other places of temporary residence (hostels, motels and guest houses - in total 89 objects), a correlation between them and cultural objects became noticeable (Figure 7). This map makes it possible to identify places where the additional placement of tourist infrastructure will be the most justified.

The map in Figure 7 can be used by both tourists and managers to organize tourist activities on the territory. It can help to tell how to plan a tourist route in order to visit more attractions in a shorter time. Small colored loci that merge into one area are the most attractive places to stop by. Dark loci that do not have hotels nearby could be appealing for opening new hotels. Thus, this cartographic method provides more informative results, in comparison with a point display of tourist locations, by means of a chart diagram or a cartogram.

\subsection{The fourth cartographic method}

The final method that I propose to use for analyzing tourist attractive regions is mapping with a density surface. Such a map displays well the areas of concentration of point objects and indicates their density (Mitchell, 2000). The density surface can be illustrated using the so-called heatmaps (Kulyk \& Sossa, 2018).

In Figure 8 I show a heatmap of the density of distribution of historical and cultural objects in Chernihiv region, which is built using a plug-in (module) of QGIS. To enhance the visual illustration, contour lines are also plotted on the map. These are the lines with the same density value. This map not only clearly visualizes the distribution of attractive objects, but also helps to identify areas where the objects are completely absent. Therefore, it is useful for identifying tourist-depressed areas. The development of tourist infrastructure in such areas is unlikely to be effective since tourists do not visit often these areas due to the lack of tourist attractions.

\section{Conclusions}

In this study, I compare 4 cartographic methods that can be used to analyze the tourist attractiveness of a region

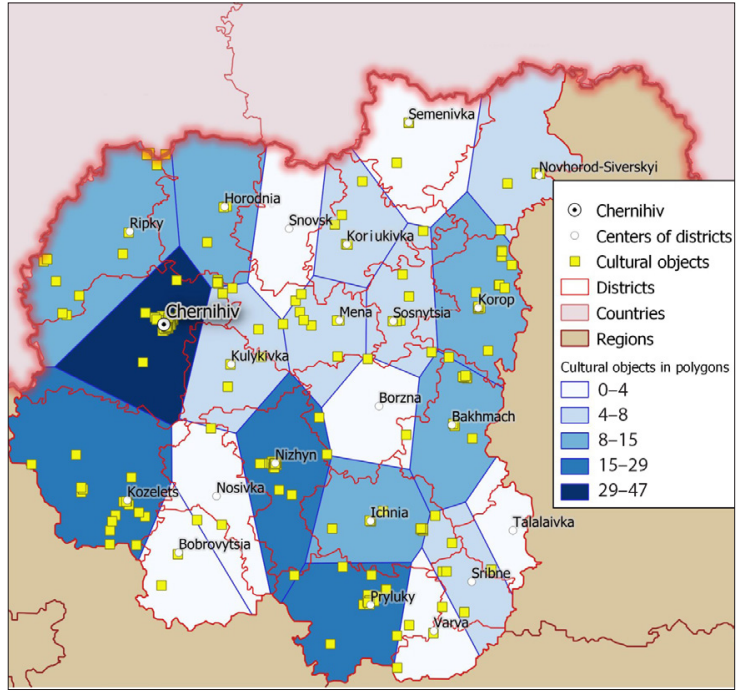

Figure 6. A Voronoi diagram of historical and cultural objects of Chernihiv region with loci around the centers of the districts

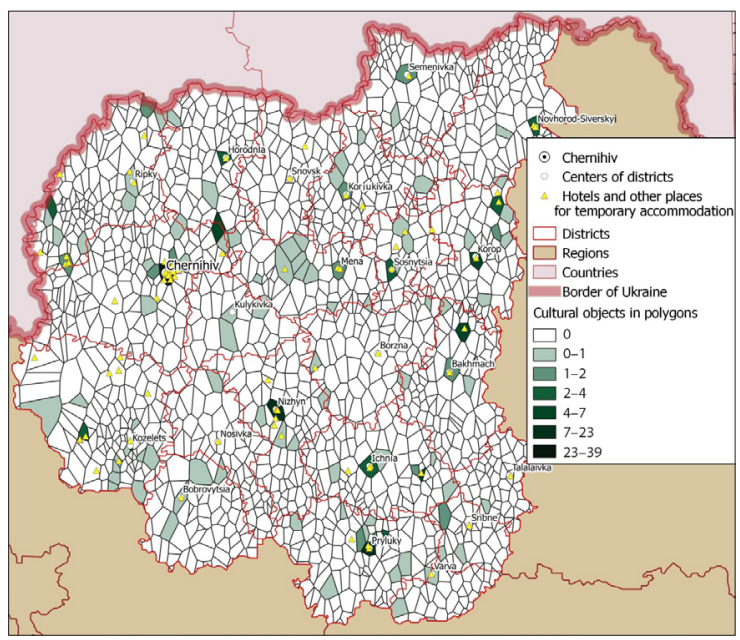

Figure 7. A Voronoi diagram of historical and cultural objects of Chernihiv region with loci around cities, urban settlements and villages

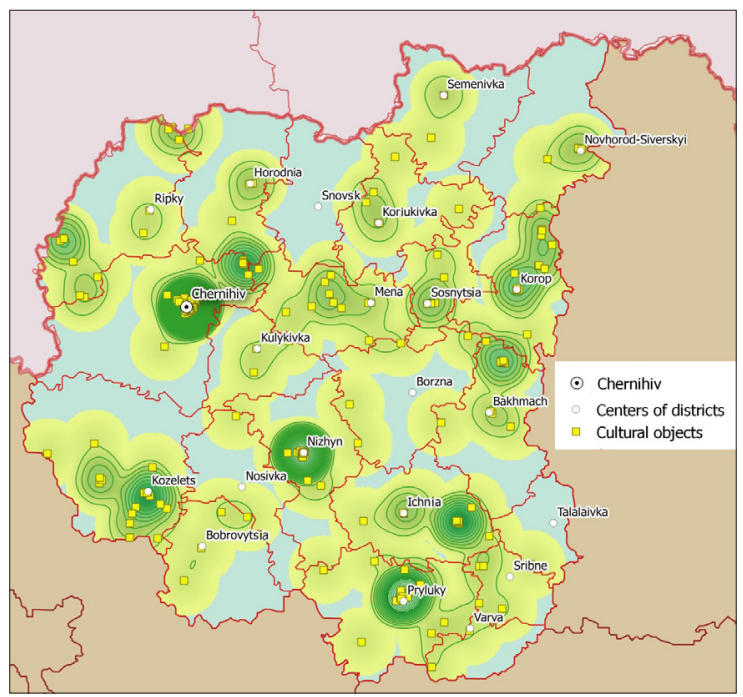

Figure 8. A heatmap of the distribution density of historical and cultural objects in Chernihiv region 
with the use of GIS technologies. For the first time, the mapping of a territory by dividing it into loci was used to study tourist attractive regions.

I apply all the methods to Chernihiv region of Ukraine. As a result of the study, I confirm that Chernihiv region is quite attractive for tourists. Most importantly, I identify the most attractive territories of this region according to the number of historical and cultural objects. Such tourist attractive territories are areas around Chernihiv, Nizhyn and Pryluky. The least attractive territories are located around Snovsk and Talalaivka.

Each cartographic method used in this study can help to analyze the territory for a specific purpose. The analysis of the distribution of tourism facilities by districts is important mainly for administrative authorities in planning the development of the territory. It allows to compare administrative districts one with another and to highlight those that need additional investment in tourism. The method of using the surface density is the most straightforward. It provides a qualitative assessment of tourist attractiveness without any reference to administrative districts or their centers. The method of finding the nearest neighbor can be used to compare loci around settlements based on their quantitative characteristics. This method can also be used to identify potential suitable locations for tourism facilities. However, one disadvantage of the last two methods is that the attractiveness of tourist objects is evaluated according to the actual distance to them. In the real world, tourists do not travel directly but use the transportation infrastructure. Nonetheless, given the well-developed road infrastructure in Chernihiv region I assume that the obtained results are quite practical.

The proposed methodologies of determining tourist attractive regions can be used to obtain fairly objective results. A deeper study can be conducted if additional categories of tourist objects are included in the analysis, as well as if the attendance of each tourist object is taken into account. With more data, the results can be more accurate and reliable.

\section{References}

Barliani, I. Ya. (2015). Ispolzovanie geoinformatsionnyih sistem $v$ turisticheskom biznese. Retrieved December 1, 2019, from https://cyberleninka.ru/article/v/ispolzovanie-geoinformatsionnyh-sistem-v-turisticheskom-biznese

Izotova, M. A., \& Matyuhina, Yu. A. (2006). Innovatsii v sotsiokulturnom servise i turizme. Nauchnaya kniga.
Kruzhalin, V. I., Mironenko, N. S., Zigern-Korn, N. V., \& Shabalina, N. V. (2014). Geografiya turizma: uchebnik. Federalnoye agentstvo po turizmu.

Kulyk, V., \& Sossa, R. (2018). Determining the tourist attractive regions by GIS analysis using heatmaps. Geodesy and Cartography, 44(1), 22-27. https://doi.org/10.3846/gac.2018.882

Melkonian, G. A. (2019). Vprovadzhennia GIS-tekhnologii u turystychnii sferi. Materialy Mizhnarodnoi naukovo-prakticznoi konferencii: Problemy ta perspektyvy rozvytku suchasnoi nauky. NUVGP. http://tourlib.net/statti_ukr/melkonyan.htm

Melnik, A. V. (2009). Vprovadzhennia ta vdoskonalennia geoinformatsiinykh tekhnologii u turystychnii diialnosti. Naukovyi visnyk UzhNU, Seriia "Ekonomika", (28), 43-44.

Mitchell, E. (2000). Rukovodstvo po GIS-analizu. Ch. 1: Prostranstvennye modeli i vzaimosvyazi. ZAO ECOMM Co.

Preparata, F., \& Sheymos, M. (1989). Vyichislitelnaya geometriya: Vvedenie. Mir. http://algolist.manual.ru/maths/geom/prsh/

Pshenichnyih, Yu. A. (2006). Metodyi otsenki ekonomicheskoy ustoychivosti razvitiya turisticheskoy otrasli. Turizm i rekreatsiya: fundamentalnyie i prikladnyie issledovaniya. Trudyi mezhdun. nauch.-prakt. konferencii (pp. 163-166). RIB “Turist”.

Salishchev, K. A. (1990). Kartovedenie. Izd-vo MGU.

Shnyirkova, A. A., \& Zhihareva, O. I. (2016). Ispolzovanie geoinformatsionnyih tehnologiy dlya sozdaniya shemyi territorialnogo planirovaniya $\mathrm{v}$ turizme na primere basseyna reki Sogozhi Yaroslavskoy oblasti. Jelektronnyj sbornik statej po materialam XLVI studencheskoj mezhdunarodnoj zaochnoj nauchno-prakticheskoj konferencii, 9(45), 65-69. https://sibac.info/archive/technic/9(45).pdf

Tagan, T. A. (2009). Cartographic method in the study of territorial recreational inequality. Culture of the Peoples of the Black Sea, 176, 182-185.

Umrik, M. A. (2011). Suchasni informatsiini tekhnologii v turyzmi. Programa "Google Earth". Naukovyi chasopys NPU im. M. Dragomanova. Seriia 5. Pedagogichni nauky: realii ta perspektyvy, 28, 287-292.

http://enpuir.npu.edu.ua/bitstream/123456789/1055/1/59.pdf

Vishnyakova, N. N. (2015). Formirovanie turprodukta pod zaprosyi potrebitelya. Individualnyiy i gruppovoy turizm. Muzeynoe delo i turizm kak faktoryi razvitiya rossiyskoy glubinki: materialyi II Vseros. nauchno-prakticheskovo foruma (pp. 74-83). MBUK “Totemskoe muzeynoe ob'edinenie”. https://turist.edu.yar.ru/publikatsii/2015_totma/sbornik_materialov_forum_totma_2015.pdf

Yakovenko, I. M. (2003). Geoinformatsiya v kartograficheskih issledovaniyah regionalnogo rekreatsionnogo prirodopolzovaniya. Kultura narodov Prichernomorya, 38, 16-20.

Zaharkin, I. (2016). Diagramma Voronogo i eyo primeneniya. https://habr.com/ru/post/309252/\#Part3 